\title{
PATIENTS WITH CHRONIC HEPATITIS C AND NORMAL TRANSAMINASES
}

Haydée Marina do Valle PEREIRA(1), Norma de Paula CAVAlHeiro(2), Fátima Mitiko TENGAN(2), Carlos Eduardo MELO(2), Evandro Sobroza de MELLO(3) \& Antônio Alci BARONE(2)

\begin{abstract}
SUMMARY
Hepatitis $\mathrm{C}$ virus infection evolves progressively persisting in the majority of patients (85\%). Most patients have high ALT (alanine aminotransferase) levels and approximately 25\% normal ALT. The latter are usually female and there is no association between genotype and severity of hepatic lesion. Histologic analysis usually shows small lesion and absence or low amount of fibrosis, despite cirrhosis having been reported. Aiming at assessing prevalence, demographic, genotypical and anatomopathological characteristics in patients with normal ALT levels, we have carried out a study of 68 chronic hepatitis C patients between January 1997 and April 2000. There was a prevalence of 13.8\% chronic hepatitis C patients with normal ALT levels, $45.6 \%$ of which were male and $54.4 \%$ female, the mean age being 38 +/- 13 years. We found a predominance of genotype 1 in $84.7 \%$ of the patients, genotype 2 in $6.8 \%$ and genotype 3 in $10.7 \%$. In $52.9 \%$ of the cases liver biopsies revealed liver reaction, periportal activity score $0-1$ was observed in $85.3 \%$ of the patients and score $2-4$ was seen in $14.7 \%$. Structural activity score $0-1$ was seen in $73.5 \%$ of the patients and score $2-4$ in $26.5 \%$ of them. Periportal activity $\geq 2$ and structural activity $>1$ was seen in $29 \%$, but steatosis was not seen in $73.5 \%$. Our results suggest the need to revisit for liver biopsy practice in patients with Chronic Hepatitis C and normal transaminases.
\end{abstract}

KEYWORDS: Hepatitis C; Normal transaminases; Biopsy.

\section{INTRODUCTION}

In spite of new hepatitis $\mathrm{C}$ virus (HCV) infections having declined in the last decade in most developed countries, chronic hepatitis $\mathrm{C}$ is still a major public health concern.

An estimated 200 million people are currently chronically infected with $\mathrm{HCV}^{25}$. $75 \%$ of these patients have elevated ALT levels and in 20 to $30 \%$ ALT levels are normal ${ }^{29}$. HCV has become one of the major causes of elevated aminotransferases in asymptomatic patients.

Serum aminotransferases testing has been widely used as a marker of liver disease activity, however, the literature has objected to this finding, because liver biopsies carried out in patients with normal transaminases show some degree of hepatic lesion, although, in most cases, histopathology of the lesion is mild and progression to fibrosis lower than in patients with elevated ALT, thus, denying the healthy virus carrier paradigm ${ }^{3}$.

POYNARD et al. ${ }^{20}$ have studied liver fibrosis progression by analyzing large series of previously untreated $\mathrm{HCV}$ patients, with a defined date of contamination and an average annual liver fibrosis progression rate calculated by means of a single liver biopsy specimen. Poynard's study originated a model suggesting a broad spectrum of progression and defining three groups of patients with fibrosis: those with slow progression fibrosis (cirrhosis over 50 years of age), moderate fibrosis (cirrhosis at 20 to 50 years of age), or rapid progression fibrosis (period of infection under 20 years). The literature shows that patients with normal ALT can represent the relatively slow fibrosis progression rate population ${ }^{12,13,16,19}$.

There are currently six identified HCV genotypes and at least 80 subtypes ${ }^{7}$. In $1994^{28}$, the nomenclature was standardized classifying HCV genotypes. The six different genotypes and the, at least, 80 genotypes have proven to vary geographically. Genotypic diversity affects numerous aspects of the disease for several reasons: in regard to $\mathrm{HCV}$ epidemiology because it varies geographically and also because determining the genotype is essential for studying the routes of infection; in regard to HCV pathogenicity because HCV strains have different levels of virulence, which may be responsible for co-infection with multiple genotypes, in regard to HCV treatment because different genotypes respond differently to medication. 
This study was carried out as part of a study protocol at the Medical Investigation Laboratory for Hepatitis (LIM-47) aimed at studying HCV and normal enzymes.

\section{PATIENTS AND METHODS}

Sixty-eight patients who were in accompaniment for chronic hepatitis $\mathrm{C}$ at the viral hepatitis clinic at the Infectious and Parasitary Diseases Department at the University of São Paulo School of Medicine were studied from January 1, 1997 to April 30, 2000.

Inclusion criteria were positivity for anti-HCV serology (immunoenzymatic method) by third and second generation ELISA, RNA-HCV detection by qualitative and/or quantitative PCR methods, a minimum of three normal (or 1.5-fold ULN) ALT levels over a 12month period and a representative liver tissue specimen for histopathological analysis.

Routine biochemical tests were performed at the HC-FMUSP Central Laboratory according to the manufacture's standardized procedures (Diagnostics Corporation, Indianapolis, U.S.A.).

Medical residents at the Parasitary and Infectious Diseases Department carried out percutaneous liver biopsies preceded by ultrasound. Specimens were fixed in a $10 \%$-solution of formalin and were subsequently stained with hematoxylin-eosin, Perls', Mason's trichrome and reticulin. All biopsy specimens were examined by a single pathologist according to the histopathologic and staging classification system of the Brazilian Society of Pathology ${ }^{10}$.

Genotyping was carried out on stored samples at the Laboratory for Hepatitis - LIM 47. 5'NC region was analyzed with PCR and genotyping tests.

\section{Genotyping HCV}

TRUGENE HCV 5'NC genotyping kit: a 244-bp fragment from the 5'NC of the HCV genome was amplified by RT-PCR using the COBAS AMPLICOR Hepatitis C test (Roche Molecular Systems, Inc., Branchburg, N.J.). The amplified products were purified with the QIAquick PCR purification kit (Quiagen, Inc., Valencia, CA) and sequenced with the TRUGENE HCV 5'NC Genotyping Kit according to the manufacturer instructions (Bayer Health Care Diagnostics, Berkeley, CA, USA). All HCV sequences were analyzed with the OpenGEne DNA sequencer and Gene Object sequence analysis software $(\mathrm{GL} 3.1 .2)^{11}$.

\section{Serotyping analysis}

Serotypes were determined by the Murex HCV serotyping 1-6 assay. This assay is used for the detection of type-specific NS4 derived epitopes, presented as branched peptides in a microliter 96-well format. Serotyping was performed according to the manufacturer's instructions. The results were scored as specific serotypes, multiple serotypes, no type-specific antibodies or non-reactive, according to the interpretation criteria established ${ }^{30}$

The Ethics Committees at both the Infectious and Parasitary Diseases
Department and at the Hospital das Clinicas have approved this study.

\section{DATA ANALYSIS}

The proportion of patients with ALT serum levels less than or equal to 1.5-fold ULN was calculated as a simple frequency, that is, the ratio between the number of patients with normal ALT levels or with up to 1.5 -fold ULN and the total number of patients that received assistance at the clinic.

Considering the total number of patients chronically infected with HCV with normal ALT or ALT up to 1.5-fold ULN, assisted at the Viral Hepatitis Clinic at the Infectious Diseases and Parasitary Department at HC-FMUSP, during the period of January 1, 1997 and April 4, 2000 we calculated:

a. The distribution of patients according to gender, age group, presence of steatosis, and genotype;

b. The distribution of patients according to liver tissue structural alteration.

\section{RESULTS}

Prevalence of chronic hepatitis C and normal ALT (or 1.5 fold ULN) levels found was of 68/492 or $13.82 \%$ (CI 95\%: $10.90 \%$; $17.19 \%$ ), of which $31(45.6 \%)$ were men and $37(54.4 \%)$ women. Patients' age varied from 18 to 71 years of age, with mean age being $38+/-13$ years.

According to Figure 1, 73.5\% of the 68 patients presented periportal activity score $0-1$ and $26.5 \%$ of them periportal activity score $2-4$. In terms of structural activity, in $85.3 \%$ of the cases patients scored $0-1$ and in $14.7 \%, 2-4$.

Eighteen out of sixty-eight or $26.5 \%$ of the patients had liver steatosis, of which 17 had mild steatosis and one moderate steatosis of the liver. Of the total number of patients, 50 (73.5\%) had no liver steatosis at all.

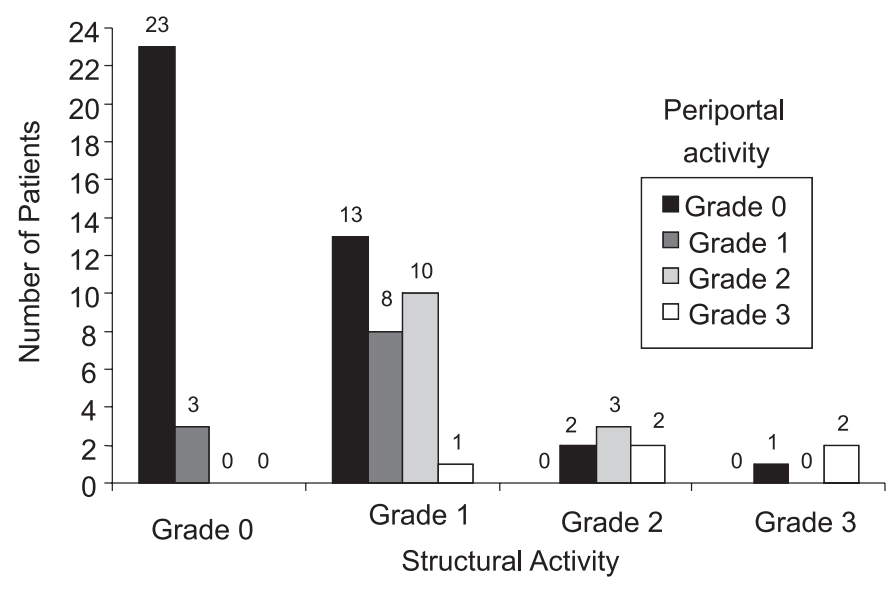

Fig. 1 - Distribution of patients with chronic hepatitis and normal ALT activity according periportal and structural activities.

Of 68 patients, 32 had chronic hepatitis. Of the latter, periportal activity (PPA) 0 and structural activity (SA) 0 were seen in three 
patients; PPA 1 and SA 1, in eight; PPA 1 and SA 2, in two; PPA 1 and SA 3, in one; PPA 2 and SA 1, in ten; PPA 2 and SA 2, in three, PPA 3 and SA 1, in one; PPA 3 and ASA 2, in two. Cirrhosis was not seen in any of the 32 patients.

Genotyping was carried out in 59 patients. 50 were genotype 1, of which seven were genotype 1,25 were subtype $1 \mathrm{~b}, 17$ subtype $1 \mathrm{a}$, and a mixed subtype $1 \mathrm{a} / 1 \mathrm{~b}$ was present in one patient. Four patients were genotype 2, of which one was genotype 2 and three patients were subtype $2 \mathrm{~b}$. Five patients were genotype $3 \mathrm{a}$ as shown in Table 1 below.

Table 1

Distribution of chronic hepatitis C patients and normal ALT activity according to genotypes

\begin{tabular}{ccc}
\hline Genotypes & Number of patients & $(\%)$ \\
\hline 1 & 7 & 11.9 \\
$1 \mathrm{a}$ & 17 & 28.8 \\
$1 \mathrm{~b}$ & 25 & 42.4 \\
$1 \mathrm{a} / \mathrm{b}$ & 1 & 1.7 \\
2 & 1 & 1.7 \\
$2 \mathrm{~b}$ & 3 & 5.0 \\
$3 \mathrm{a}$ & 5 & 8.5 \\
\hline Total & 59 & 100.0 \\
\hline
\end{tabular}

\section{DISCUSSION}

Prevalence of hepatitis C with normal ALT varies from $7.5 \%$ to $46 \% 1,15,16,17,19,22$. The $13.8 \%$ prevalence rate found is confirmed by the literature. All patients with normal ALT and ALT 1.5-fold ULN were included in this study and underwent liver biopsy. However, patients with only one or two ALT measurements in a year were not included and this probably contributed to a decreased prevalence rate.

The variation between the prevalence established in this study and prevalence rates in the literature is due to the fact that only patients with persistently normal ALT levels and patients with minimally raised ALT were included, to the variation in ALT levels obtained and to the lack of data on alcohol intake.

Therefore, this study included patients with normal ALT and patients with ALT not exceeding 1.5-fold ULN. Patients were selected according to the criteria in PUOTI et al., which classify patients in two groups: the biochemically silent, with persistently normal ALT levels, and patients with minimally raise $\mathrm{ALT}^{18}$. 54.4\% were women and $45.6 \%$ were men, although several studies indicate the prevalence of women in this population ${ }^{24,26,27}$, this possibly suggests a protective effect of estrogens, which block the proliferation of stellate cells and fibrogenesis ${ }^{21}$. Another possibility is that, histologically, due to the different living styles adopted by men and women, especially concerning alcohol intake, which is a well-known factor in the pathological evolution process, the disease could be milder in women ${ }^{21}$.

Patients' age varied between 18 and 71 years of age, being the mean age $38+/-13$ years, which corresponds to the expected age according to ALTER et al. ${ }^{2}$ and FOCCACIA et al. ${ }^{8}$.
In regard to $\mathrm{HCV}$ genotypes, we found a prevalence of genotype 1 in $84.8 \%$ of the patients, followed by genotype 3 in $8.5 \%$ and by genotype 2 in $6.7 \%$. These findings are similar to the findings in CAVALHEIRO et al. ${ }^{6}$ and BASSIT et al. ${ }^{3}$, who, in turn, do not determine ALT levels.

Genotype distribution found here is similar to that of Europe where there is also a prevalence of genotypes 1 and 3 , and where dissemination probably occurred by means of blood transfusion.

PUOTI et al. compared a group of patients with elevated ALT and a group of patients with normal ALT and did not find an association in either group between HCV genotype and degree of liver lesion ${ }^{24}$. This argument can be used against the predictive value of genotype.

Among the histological characteristics, steatosis has appeared as a fibrosis progression factor and is a common finding in chronic hepatitis $\mathrm{C}$.

Serotyping for characterizing HCV type by immunoenzymatic method (ELISA) was performed in nine patients, because, although in at least one moment, these patients tested positive for RNA-HCV with $\mathrm{PCR}$, in the samples examined retrospectively only results negatives for $\mathrm{HCV}$ were available.

Previous studies have also highlighted aspects of the relation between steatosis and HCV. Among said aspects, we can find high BMI and high levels of triglycerides ${ }^{14}$. In this study, information on BMI, triglyceride and glucose levels were not available in view of the fact that this is a retrospective study, and characteristics such as weight, height, triglyceride levels, were not always recorded on the patients' charts.

Cross-sectional studies indicate that liver steatosis may be a consequence of a cytopathic effect of hepatitis $\mathrm{C}$ virus, specially in patients infected with genotype 3 . Steatosis is seen in approximately 30 to $70 \%$ of hepatitis C patients ${ }^{14}$.

In this study, steatosis was seen in $26.5 \%$ of the patients, of which only one had grade 2 steatosis; steatosis was not seen in $73.5 \%$; and $10.5 \%$ were infected with genotype 3 . These factors lead us to the hypothesis that fibrosis evolves at a lower rate in this population.

According to previous research, the data in this study show that the presence of HCV RNA is associated to the lesion, despite normal ALT activity. This suggests that the determination of chronic hepatitis, which is currently based on abnormal liver biochemical testing, should be reexamined since liver lesions are usually found in patients with normal ALT. Of 68 patients, in 52.9\% of the cases biopsies showed liver reaction (reactional liver), which, according to the Brazilian Society of Pathology, reveals relatively smaller lesions than those considered to be hepatitis, but, even so, these lesions are not within the normality rates, because of the minimal aggressive action of the virus or of the nonspecific response of liver cells to other systemic procedures ${ }^{10}$.

The spectrum of liver lesions found in patients with chronic hepatitis $\mathrm{C}$ and normal ALT varies, but there is a general consensus in the literature that, in most cases, histological lesions are mild. The data in this study 
are similar to those described in the literature ${ }^{1,9,18,24}$ according to which, although fibrosis takes place, it occurs less than in patients with elevated ALT, possibly because of the correlation between intensity of necroinflammatory activity and progression to fibrosis; so the histological lesions are milder pursuant to a recent study by FONTAINE et al. ${ }^{9}$.

According to world consensus, mild to severe hepatitis and compensated cirrhosis must be treated and the current criteria in effect established by the Brazilian Health Ministry in $2002^{4}$, stating that patients with PPA $>2$ and/or SA $>1$, which corresponds to $29 \%$ of the patients in this study, recommend antiviral treatment. ZEUZEM et $a l .{ }^{31}$ in 2004 concluded that the efficacy and safety of peginterferon alfa- $2 \mathrm{a}$ and ribavirin combination therapy in patients with chronic hepatitis $\mathrm{C}$ and persistently normal ALT levels are similar to that in patients with elevated ALT levels. The indication for treatment of hepatitis $\mathrm{C}$ can be evaluated independently from baseline ALT activity. This confirms that carrying out biopsies regardless of ALT levels, can contribute to tranquilizing patients with small lesions (who constitute the majority of the population), identifying severe liver lesions and selecting patients for treatment.

\section{RESUMO}

\section{Pacientes com hepatite $\mathrm{C}$ crônica e transaminases normais}

Hepatite C é uma doença de evolução progressiva. A maioria dos pacientes tem nível de ALT elevada e $25 \%$ apresentam níveis normais. Os com ALT normal geralmente são do gênero feminino e sem associação entre genótipo e gravidade de lesão hepática. O exame histopatológico mostra geralmente ausência de ou leve fibrose (cerca de $20 \%$ tem fibrose), embora cirrose já tenha sido relatada. Visando estimar a prevalência, características demográficas, genotípicas e anatomopatológicas em pacientes com ALT normal, realizamos um estudo de série com 68 casos com diagnóstico de hepatite C crônica. Os pacientes foram selecionados de janeiro de 1977 a abril de 2002. Encontrou-se uma prevalência de 13,8\% (45,6\% masculinos). A média de idade foi $39+/-13$ anos. Predomínio de genótipo 1 (84,8\%), seguido pelo $3(8,5 \%)$ e $2(6,7 \%)$. Encontramos fígado reacional em $52,9 \%$ das biópsias, atividade periportal de $0-1$ em $85,3 \%$ e atividade periportal de $2-4$ em 14,7\%. Apresentaram atividade estrutural de 0 a $173,5 \%$ e 26,5\% com atividade estrutural de 2 a 4, sendo que $29 \%$ da amostra apresentou APP $\geq 2$ e AE $>1 ; 73,5 \%$ não apresentaram esteatose. Nossos dados reforçam a necessidade de biópsia em pacientes com hepatite $\mathrm{C}$ e níveis de ALT normais.

\section{ACKNOWLEDGEMENT}

We would like to acknowledge the "Fundação de Amparo à Pesquisa do Estado de São Paulo" (FAPESP) for funding part of this study.

\section{REFERENCES}

1. AlBerti, A.; NOVENTA, F.; BENVEGNU, L.; BOCCATO, S. \& GATTA, A. Prevalence of liver disease in a population of asymptomatic persons with hepatitis $\mathrm{C}$ virus infection. Ann. intern. Med., 137: 961-964, 2002.

2. ALTER, M.J.; KRUSZON-MORAN, D.; NAINAN, O.V. et al. - The prevalence of hepatitis C virus infection in the United States, 1988 through 1994. New Engl. J. Med., 341: 556-562, 1999.
3. BASSIT, L.; RIBEIRO-DOS-SANTOS, G.; DA SILVA, L.C. et al. - Genotype distributions of hepatitis C virus in São Paulo, Brazil: rare subtype found. Hepatology, 29: $994-$ 995, 1999.

4. BRASIL. MINISTÉRIO DA SAÚDE. SECRETARIA DE ASSISTÊNCIA À SAÚDE. DEPARTAMENTO DE SISTEMAS E REDES ASSISTENCIAIS - Protocolo clínico e Diretrizes Terapêuticas. Hepatite Viral Crônica C. Portaria 863. Brasilia, 2002.

5. BRILLANTI, S.; FOLI, M.; GAIANI, S. et al. - Persistent hepatitis C viraemia without liver disease. Lancet, 341: 464-465, 1993.

6. CAVALHEIRO, N.P.; BARONE, A.A. \& TENGAN, F.M. - HCV serotypes in Brazilian patients. Int. J. infect. Dis., 6: 228-232, 2002.

7. DAVIS, G.L. - Hepatitis C virus genotypes and quasispecies. Amer. J. Med., 107(6B): 21S-26S, 1999.

8. FOCACCIA, R.; DA CONCEIÇÃO, O.J.; SETTE Jr., H. et al. - Estimated prevalence of viral hepatitis in the general population of the municipality of São Paulo, measured by a serologic survey of a stratified, randomized and residence-based population. Braz. J. infect. Dis., 2: 269-284, 1998.

9. FONTAINE, H.; NALPAS, B.; POULET, B. et al. - Hepatitis activity index is a key factor in determining the natural history of chronic hepatitis C. Hum. Path., 32: 904-909, 2001.

10. GAYOTTO, L.C.C. \& COMITÊ SBP/SBH - Visão histórica e consenso nacional sobre a classificação das hepatites crônicas. GED, 19: 137-140, 2000.

11. GERMER, J.J.; MAJEWSKI, D.W.; ROSSER, M. et al. - Evaluation of the TRUGENE HCV 5'NC genotyping kit with the new GeneLibrarian module 3.1.2 for genotyping of hepatitis C virus from clinical specimens. J. clin. Microbiol., 41: 4855-4857, 2003

12. HERVE, S.; SAVOYE, G.; RIACHI, G. et al. - Chronic hepatitis C with normal or abnormal aminotransferase levels: is it the same entity? Europ. J. Gastroent. Hepat., 13: 495-500, 2001.

13. JAMAL, M.M.; SONI, A.; QUINN, P.G. et al. - Clinical features of hepatitis C-infected patients with persistently normal alanine transaminase levels in the Southwestern United States. Hepatology, 30: 1307-1311, 1999.

14. KUMAR, D.; FARRELL, G.C.; FUNG, C. \& GEORGE, J. - Hepatitis C virus genotype 3 is cytopathic to hepatocytes: reversal of hepatic steatosis after sustained therapeutic response. Hepatology, 36: 1266-1272, 2002.

15. MARCELLIN, P.; LEVY, S. \& ERLINGER, S. - Therapy of hepatitis C: patients with normal aminotransferase levels. Hepatology, 26(suppl. 1): 133S-136S, 1997.

16. MATHURIN, P.; MOUSSALLI, J.; CADRANEL, J.F. et al. - Slow progression rate of fibrosis in hepatitis $\mathrm{C}$ virus patients with persistently normal alanine transaminase activity. Hepatology, 27: 868-872, 1998.

17. PARANA, R.; VITVITSKI, L.; BERBY, F. et al. - HCV infection in northeastern Brazil: unexpected high prevalence of genotype $3 \mathrm{a}$ and absence of African genotypes. Arq. Gastroent. (S. Paulo), 37: 213-216, 2000.

18. PASQUALE, G.; SAGNELLI, E.; COPPOLA, N. et al. - Is liver biopsy necessary for hepatitis $\mathrm{C}$ virus carriers with persistently normal aminotransferase levels? Europ. J. Gastroent. Hepat., 15: 831-833, 2003.

19. PERSICO, M.; PERSICO, E.; SUOZZO, R. et al. - Natural history of hepatitis C virus carriers with persistently normal aminotransferase levels. Gastroenterology, 118: 760-764, 2000.

20. POYNARD, T.; BEDOSSA, P. \& OPOLON, P. - Natural history of liver fibrosis progression in patients with chronic hepatitis C. The OBSVIRC, METAVIR, CLINIVIR, and DOSVIRC groups. Lancet, 349: 825-832, 1997. 
21. POYNARD, T.; RATZIU, V.; CHARLOTTE, F. et al. - Rates and risk factors of liver fibrosis progression in patients with chronic hepatitis C. J. Hepat., 34: 730-739, 2001

22. PRADAT, P.; ALBERTI, A.; POYNARD, T. et al. - Predictive value of ALT levels for histologic findings in chronic hepatitis C: a European collaborative study. Hepatology, 36: $973-977,2002$.

23. PUOTI, C.; MAGRINI, A.; STATI, T. et al. - Clinical, histological, and virological features of hepatitis $\mathrm{C}$ virus carriers with persistently normal or abnormal alanine transaminase levels. Hepatology, 26: 1393-1398, 1997.

24. PUOTI, C.; CASTELLACCI, R.; MONTAGNESE, F. et al. - Histological and virological features and follow-up of hepatitis $\mathrm{C}$ virus carriers with normal aminotransferase levels: the Italian prospective study of the asymptomatic C carriers (ISACC). J. Hepat., 37: 117-123, 2002

25. RIESTRA, S.; FERNANDEZ, E.; LEIVA, P. et al. - Prevalence of hepatitis C virus infection in the general population of northern Spain. Europ. J. Gastroent. Hepat., 13: $477-481,2001$.
26. SHAKIL, A.O.; CONRY-CANTILENA, C.; ALTER, H.J. et al. - Volunteer blood donors with antibody to hepatitis $\mathrm{C}$ virus: clinical, biochemical, virologic, and histologic features. The Hepatitis C Study Group. Ann. intern. Med., 123: 330-337, 1995.

27. SHINDO, M.; ARAI, K.; SOKAWA, Y. \& OKUNO, T. - The virological and histological states of anti-hepatitis $\mathrm{C}$ virus-positive subjects with normal liver biochemical values. Hepatology, 22: 418-425, 1995.

28. SIMMONDS, P.; ALBERTI, A.; ALTER, H.J. et al. - A proposed system for the nomenclature of hepatitis C viral genotypes. Hepatology, 19: 1321-1324, 1994

29. TASSOPOULOS, N.C. - Treatment of patients with chronic hepatitis C and normal ALT levels. J. Hepat., 31: 193-196, 1999.

30. VAN DOORN, L.J.; KLETER, B.; PIKE, I. \& QUINT, W. - Analysis of hepatitis C virus isolates by serotyping and genotyping. J. clin. Microbiol., 34: 1784-1787, 1996.

31. ZEUZEM, S.; DIAGO, M.; GANE, E. et al. - Peginterferon alfa-2a (40 kilodaltons) and ribavirin in patients with chronic hepatitis $\mathrm{C}$ and normal aminotransferase levels. Gastroenterology, 127: 1724-1732, 2004

Received: 13 April 2005

Accepted: 15 August 2005 